\title{
Occurrence and variability of Panstrongylus lutzi in the State of Ceará, Brazil
}

\author{
Ocorrência e variabilidade de Panstrongylus lutzi \\ no Estado do Ceará, Brasil
}

\author{
Maria Hismênia H.M. Garcia' ${ }^{1}$ Lindemberg Souza ${ }^{2}$, Rita de Cássia M. de Souza ${ }^{3}$, Alexandre S. Paula ${ }^{3}$, \\ Érika C. Borges ${ }^{4}$, Silvia E. Barbosa ${ }^{3}$, Christopher John Schoffield ${ }^{5}$ \\ and Liléia Diotaiuti ${ }^{3}$
}

\begin{abstract}
Panstrongylus lutzi is generally restricted to the "caatinga" areas of north-eastern Brazil. Adult insects are frequently found in local houses, but colonies have not previously been registered in the statistics of the Control Programme of Chagas Disease. In Ceará State, our study revealed increasing occurrence of this species, usually with bigh infection rates for Trypanosoma cruzi, and always represented by adults that invaded the artificial environment. We also found nymphs in the peridomicile and inside the houses. In silvatic habitats we collected two adult females from hollow tree trunks, which may represent an alternative natural ecotope for the species in this state. Panstrongylus lutzi entomological collections from Sobral and Crateús, studied by morphology and morphometrics, showed great variability; those from Crateús were larger smaller and paler in colour, with individuals showing genital features consistent with those described for Panstrongylus lutzi or Panstrongylus sherlocki, whereas those from Sobral were darker and with genitalia compatible with P. sherlocki, nevertheless, all were considered to be Panstrongylus lutzi.
\end{abstract}

Key-words: Panstrongylus lutzi. Triatominae. Chagas' disease. Morphometry. Variability.

\section{RESUMO}

O Panstrongylus lutzi é um triatomíneo de ocorrência restrita às áreas de "caatinga" do Nordeste brasileiro. Apesar da presença de adultos no ambiente artificial ser freqüente, a ocorrência de colônias nunca havia sido assinalada pelas estatísticas do Programa de Controle da Doença de Chagas. No Estado do Ceará, a ocorrência desta espécie aumentou paulatinamente ao longo do período estudado, com taxas de infecção natural com Trypanosoma cruzi geralmente altas, sempre associadas a adultos que invadem o ambiente artificial. Chama a atenção o encontro de ninfas no peridomicílio e no intradomicílio. No ambiente silvestre duas fêmeas foram coletadas em troncos de árvores, que podem representar ecótopos naturais alternativos para a espécie neste Estado. As amostras de Panstrongylus lutzi dos municípios de Sobral e Crateús estudadas morfológica e morfometricamente, demonstraram alta variabilidade, sendo os insetos de Crateús significativamente menores e de coloração pálida, apresentando alguns indivíduos padrão da morfologia do falo compativel com a descrição da espécie; os insetos de Sobral eram escuros e as genitálias coincidentes com o padrão de Panstrongylus sherlocki, mas sendo todos considerados por nós como Panstrongylus lutzi.

Palavras-chaves: Panstrongylus lutzi. Triatominae. Doença de Chagas. Morfometria. Variabilidade.

\footnotetext{
1. Fundação Nacional de Saúde, Fortaleza, CE. 2. Secretaria de Estado da Saúde do Ceará, Sobral, CE. 3. Centro de Pesquisas René Rachou da Fundação Oswaldo Cruz, Belo Horizonte, MG. 4. Departamento de Bioquímica e Biologia Molecular do Instituto Oswaldo Cruz da Fundação Oswaldo Cruz. 5. LSHTM, London WC1 E7HT, UK. Supported by FIOCRUZ and ECLAT

Address to: Dra. Liléia Diotaiuti. Centro de Pesquisas René Rachou/FIOCRUZ. Av. Augusto de Lima 1715, 30190-002 Belo Horizonte, MG, Brasil.

Telefax: $55313295-3115$

e-mail: diotaiuti@cpqrr.fiocruz.br

Recebido para publicação em 3/9/2004

Aceito em 6/6/2005
} 
Panstrongylus lutzi Neiva \& Pinto, 1926 (Hemiptera, Reduviidae) is a little-studied species of Triatominae recorded from the caatinga region of northeastern Brazil (States of Ceará, Alagoas, Rio Grande do Norte, Pernambuco, Bahia, Paraíba and Sergipe) ${ }^{8}$. Its main natural habitat appears to be armadillo burrows ${ }^{8}$ and although adults have been frequently noted flying into houses, they have rarely been reported to form domestic colonies ${ }^{2}$. In the state of Ceará ${ }^{3}$, from 1964-1974, 28 adult bugs were reported entering houses in 17 municipalities (out of 141 municipalities investigated), showing a high rate of natural infection with the causative agent of Chagas' disease, Trypanosoma cruzi (17.7\%). In more recent years, routine epidemiologic surveillance by the state Chagas Disease Control Programme (National Health Foundation, Ceará State - PCDCh/FUNASA-CE) has indicated an apparent increase in the rate of house invasion by this species, which prompted the study reported here (Figure 1).

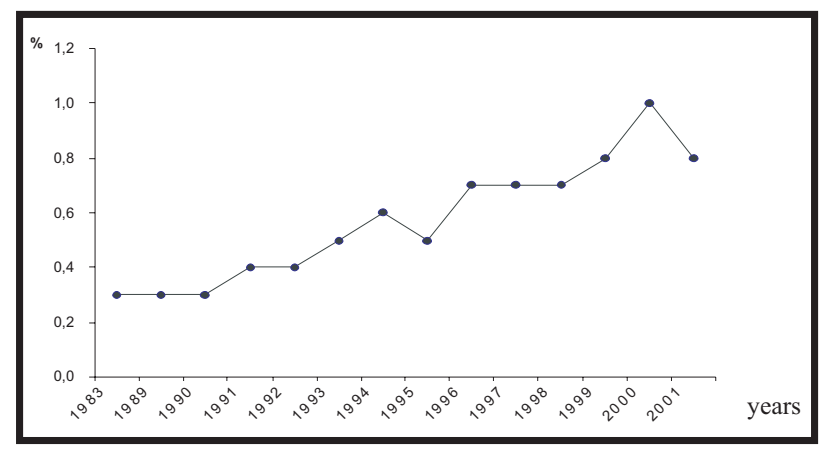

Figure 1 - Percentage of Panstrongylus lutzi in relation to the total number of triatomines captured by the Chagas Disease Control Programme in the State of Ceará, Brazil, in the year of 1983 and during the period of 1989 to 2001.

\section{MATERIAL AND METHODS}

The historical records of the PCDCh/FUNASA-CE were assessed in terms of capture reports of domestic Triatominae by the PCDCh field agents. As baseline we took the records for 1983, when field activities were expanded under the national Chagas' disease control campaign to cover almost the entire endemic area of the state. This area comprised 107 of the 141 municipalities then defined in the State of Ceará. We also analyzed the yearly capture records for the period from 1989 to 2001 which was the year when field activities were transferred to municipal authority following decentralization, and included 149 municipalities of the 184 now defined in the state. Under the current decentralized system, municipal field personnel are trained by the Fundação Nacional de Saúde (FUNASA) using similar field surveillance methods as before. This includes microscopical assessment of rates of infection with $T$. cruzi from a sample of the collected bugs (by Giemsa staining of fresh bug feces). Distributional analysis of $P$. lutzi made use of the PCDCh/FUNASA information system for the years 1983 and 2001 (Figures 2A and 2B). For 2001, but not for 1983, this system also enabled localization of records of intradomiciliary colonies (defined by the finding of nymphs in domestic habitats).

More detailed study was carried out on entomological collections of $P$. lutzi made between July 1999 and July 2000 from houses in the two municipalities of Crateús and Sobral (Figure 2A). Crateús is an arid region of caatinga-steppe, with mean annual rainfall of $758 \mathrm{~mm}$, more than 150 dry days per year ${ }^{15}$, and temperatures of $25-26^{\circ} \mathrm{C}$. Geomorphologically it is classified within the Superfície Sertaneja ${ }^{1}$, typified by preCambrian formations with open wooded steppes dominated by carnauba palms (Copernicia cerifera). Sobral is similar, but with annual mean temperatures of $26-27.5^{\circ} \mathrm{C}$, and annual precipitation reaching $1,200 \mathrm{~mm}$. Like other regions of the caatinga, both these municipalities show hydrological deficits for over 8 months per year (rainfall less than $60 \mathrm{~mm}$ in $63.9 \%$ of months, and less than $10 \mathrm{~mm}$ in $45.7 \%$ of months) $)^{4}$.

A search for natural silvatic habitats of $P$. lutzi was carried out in the rural areas of Sobral and Crateús for five days in each locality, by seeking bugs randomly in various potential ecotopes including rock-piles, under tree bark, and nests of rodents or birds. In the region of Crateús, during November 1999, we also attempted collections using a light trap (suspended white sheet illuminated by battery-operated fluorescent tube) for two consecutive nights between 18:00 and 22:00h.

Morphological analysis of $P$. lutzi from Crateús and Sobral followed the descriptions of Lent \& Jurberg $(1975)^{14}$, the insects were carefully analyzed using the most recent description by P. sherlockit $i^{14}$. Additionally, male genitalia of 10 Crateús specimens and nine from Sobral were slide-mounted for comparison with the published descriptions. Morphometric studies were carried out on 12 females and 21 males from Sobral, and 10 females and 31 males from the Crateús entomological collections. Following Dujardin et a ${ }^{10}$, six head measurements were taken from each specimen using an image analyzer system (KONTRON KS300): width of anteclypeus, length of antenniferous tubercle, anteocular distance, external distance between occelli, external distance between eyes, and post ocular distance excluding neck (Figure 3). These measurements were logtransformed and used for multivariate analysis, which included examination of variance-covariance matrices by common principal component analysis (CPCA) and discriminant analysis, performed based on the principal components to obtain shape components. All calculations were done using the software packages JMP ${ }^{17}$ and NTSYS-pc ${ }^{16}$.

\section{RESULTS}

Panstrongylus lutzi was found in almost the entire endemic area of the State of Ceará. In 1983, P. lutzi was reported from 84 (78.5\%) of the 107 municipalities included in the Chagas disease control activities (Figure 2A) represented by adult bugs alone in 70 municipalities, but with peridomestic colonies (defined by finding nymphs) reported from 14 municipalities (Tables 1 and 2). By 2001, P. lutzi was reported from 117 (78.5\%) of the 149 municipalities examined, represented by adult bugs alone in 92 municipalities, but with domestic or peridomestic colonies reported from 25 (16.8\%) municipalities; of these, intradomestic colonies were reported from 14 (9.4\%) municipalities (Figure 2B). The dispersal data does not suggest an increase in distribution 


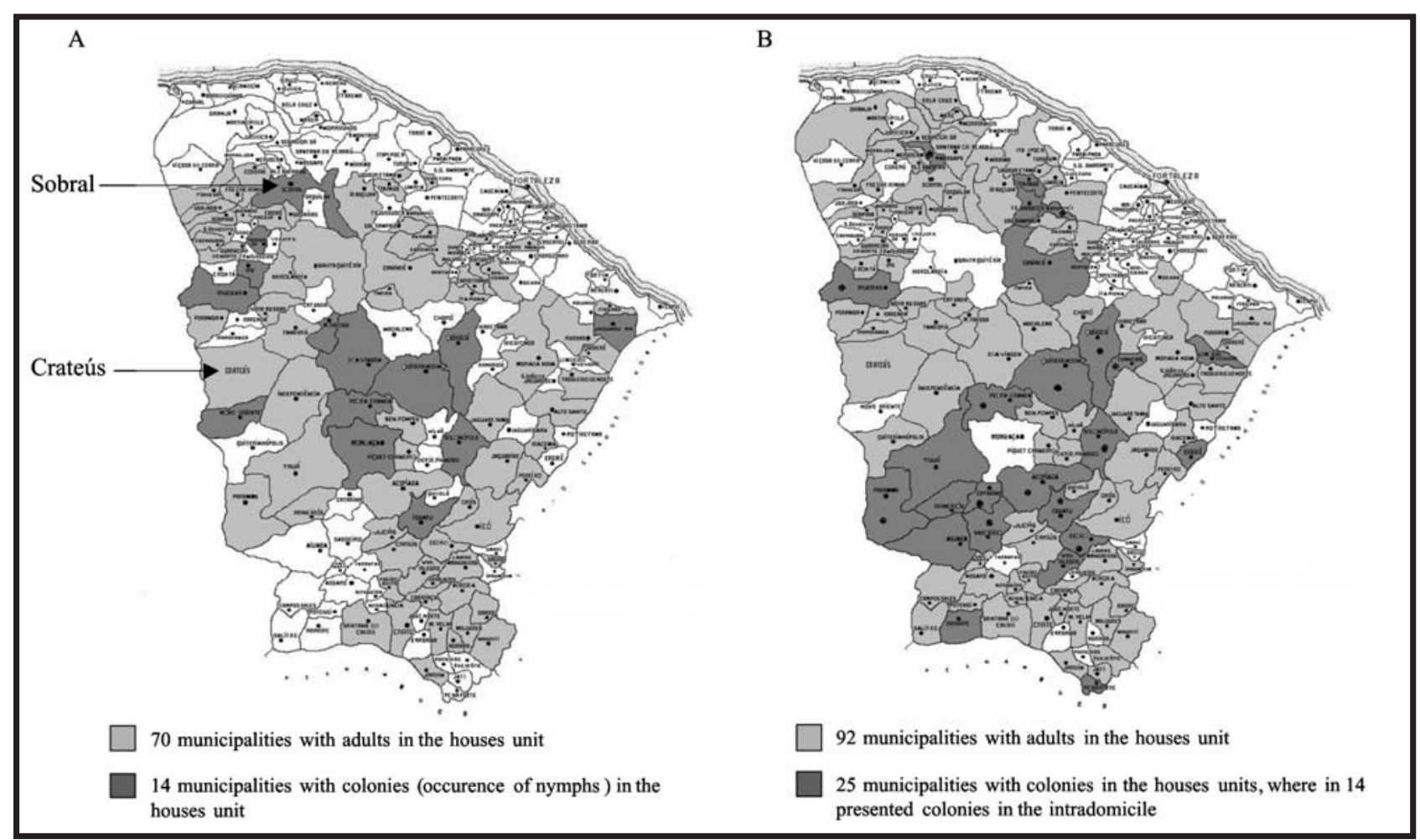

\begin{tabular}{|c|c|c|c|c|c|c|c|c|c|c|c|}
\hline \multicolumn{4}{|c|}{$\begin{array}{l}\text { Municipios do Ceará com captura de } P \text {. Iutzi nos } \\
\text { anos de } 1983 \text { e } 2001\end{array}$} & \multirow{2}{*}{$\begin{array}{l}48 \\
49 \\
50\end{array}$} & \multirow{2}{*}{$\begin{array}{l}\text { Guaraciaba do Norte } \\
\text { Hidrolândia } \\
\text { Ibaretama }\end{array}$} & \multirow[t]{2}{*}{$\begin{array}{l}x \\
x\end{array}$} & \multirow{2}{*}{$\begin{array}{l}x \\
\times\end{array}$} & \multirow{2}{*}{$\begin{array}{l}93 \\
94\end{array}$} & \multirow{2}{*}{$\begin{array}{c}\text { Ocara } \\
\text { Orós }\end{array}$} & \multirow[b]{2}{*}{$x$} & \multirow{2}{*}{$\begin{array}{l}x \\
x\end{array}$} \\
\hline $\begin{array}{l}\text { No de } \\
\text { Ordem }\end{array}$ & Municipio & 1983 & 2001 & & & & & & & & \\
\hline 1 & Abaiara & $x$ & & \multicolumn{4}{|c|}{$\begin{array}{l}\text { Municípios do Ceará com captura de } P \text {. lutzi nos } \\
\text { anos de } 1983 \text { e } 2001\end{array}$} & \multicolumn{4}{|c|}{$\begin{array}{l}\text { Municípios do Ceará com captura de } P \text {. lutzi no } \\
\text { anos de } 1983 \text { e } 2001\end{array}$} \\
\hline $\begin{array}{l}2 \\
3\end{array}$ & $\begin{array}{c}\text { Acopiara } \\
\text { Aiuaba }\end{array}$ & $x$ & $\begin{array}{l}x \\
x\end{array}$ & $\begin{array}{l}\text { No de } \\
\text { Ordem }\end{array}$ & Município & 1983 & 2001 & \begin{tabular}{|l|l|} 
No de \\
Ordem
\end{tabular} & Município & 1983 & 2001 \\
\hline 4 & Alcântara & & $\mathrm{x}$ & 51 & Ibiapina & $x$ & $\mathrm{x}$ & 95 & Pacajús & $x$ & \\
\hline 5 & Altaneira & & $\mathrm{x}$ & 52 & Icó & $x$ & $\mathrm{x}$ & 96 & Pacujá & & $\mathrm{x}$ \\
\hline 6 & Alto Santo & $\mathrm{x}$ & $\mathrm{x}$ & 53 & Iguatu & $x$ & $\mathrm{x}$ & 97 & Palmácia & $\mathrm{x}$ & \\
\hline 7 & Antonina do Norte & & $x$ & 54 & Independência & $x$ & $x$ & 98 & Parambú & $x$ & $\mathrm{x}$ \\
\hline 8 & Apuiarés & $\mathrm{x}$ & $x$ & 55 & Ipaporanga & & $x$ & 99 & Paramoti & $\mathrm{x}$ & $\mathrm{x}$ \\
\hline 9 & Aracoiaba & $\mathrm{x}$ & & 56 & Ipaumirim & & $x$ & 100 & Pedra Branca & $x$ & $\mathrm{x}$ \\
\hline 10 & Ararendá & & $x$ & 57 & Ipú & $x$ & $x$ & 101 & Penaforte & & $\mathrm{x}$ \\
\hline 11 & Araripe & & $\mathrm{x}$ & 58 & Ipueiras & $x$ & $\mathrm{x}$ & 102 & Pentecoste & & $\mathrm{x}$ \\
\hline 12 & Arneiroz & $\mathrm{x}$ & $\mathrm{x}$ & 59 & Iracema & $x$ & $x$ & 103 & Pereiro & $x$ & $\mathrm{x}$ \\
\hline 13 & Assaré & & $\mathrm{x}$ & 60 & Irauçuba & $x$ & $x$ & 104 & Piquet Carneiro & $\mathrm{x}$ & $\mathrm{x}$ \\
\hline 14 & Aurora & $\mathrm{x}$ & $x$ & 61 & Itaiçaba & $x$ & & 105 & Pires Ferreira & & $\mathrm{x}$ \\
\hline 15 & Baixio & $\mathrm{x}$ & & 62 & Itapajé & $x$ & $x$ & 106 & Poranga & $\mathrm{x}$ & $\mathrm{x}$ \\
\hline 16 & Banabuiú & & $\mathrm{x}$ & 63 & Itapipoca & & $\mathrm{x}$ & 107 & Potengi & & $x$ \\
\hline 17 & Barro & $\mathrm{x}$ & $\mathrm{x}$ & 64 & Itapiuna & $\mathrm{x}$ & & 108 & Quiterianópolis & & $x$ \\
\hline 18 & Baturité & $\mathrm{x}$ & & 65 & Itatira & $x$ & $x$ & 109 & Quixadá & $x$ & $x$ \\
\hline 19 & Bela Cruz & & $x$ & 66 & Jaguaretama & $\mathrm{x}$ & $x$ & 110 & Quixelô & & $x$ \\
\hline 20 & Boa Viagem & $\mathrm{x}$ & $\mathrm{x}$ & 67 & Jaguaribe & $x$ & $\mathrm{x}$ & 111 & Quixeramobim & $x$ & $x$ \\
\hline 21 & Brejo Santo & & $\mathrm{x}$ & 68 & Jaguaruana & $x$ & $x$ & 112 & Quixeré & $\mathrm{x}$ & $x$ \\
\hline 22 & Campos Sales & & $x$ & 69 & Jardim & $x$ & $x$ & 113 & Reriutaba & $x$ & \\
\hline 23 & Canindé & $\mathrm{x}$ & $x$ & 70 & Jati & & $x$ & 114 & Russas & $\mathrm{x}$ & $x$ \\
\hline 24 & Capistrano & $x$ & & 71 & Juazeiro do Norte & & $x$ & 115 & Saboeiro & & $\mathrm{x}$ \\
\hline 25 & Caridade & $\mathrm{x}$ & $\mathrm{x}$ & 72 & Jucás & $\mathrm{x}$ & $\mathrm{x}$ & & & & \\
\hline \multicolumn{4}{|c|}{$\begin{array}{l}\text { Municípios do Ceará com captura de } P \text {. lutzi nos } \\
\text { anos de } 1983 \mathrm{e} 2001\end{array}$} & & $\begin{array}{l}\text { Lavras da Mangabeira } \\
\text { Limoeiro do Norte }\end{array}$ & $x$ & $\begin{array}{l}x \\
x\end{array}$ & \multicolumn{4}{|c|}{$\begin{array}{l}\text { Municííios do Ceará com captura de } P \text {. lutzi nos } \\
\text { anos de } 1983 \text { e } 2001\end{array}$} \\
\hline $\begin{array}{l}\text { No de } \\
\text { Ordem }\end{array}$ & Municipio & 1983 & 2001 & \multirow{2}{*}{\multicolumn{4}{|c|}{$\begin{array}{c}75 \quad \text { Madalena } \\
\begin{array}{l}\text { Municípios do Ceará com captura de } P \text {. lutzi nos } \\
\text { anos de } 1983 \mathrm{e} 2001\end{array}\end{array}$}} & \begin{tabular}{|l|l|} 
No de \\
Ordem \\
\end{tabular} & Municipio & 1983 & 2001 \\
\hline 26 & Cariré & $x$ & $\mathrm{x}$ & & & & & 116 & Salitre & & $x$ \\
\hline 27 & Caririaçu & $x$ & $x$ & & & 1983 & 2001 & 117 & Santa Quitéria & $x$ & \\
\hline 28 & Cariús & $x$ & $x$ & Ordem & Municipio & 1983 & & 118 & Santana do Acarú & & $\mathrm{x}$ \\
\hline 29 & Carnaubal & $\mathrm{x}$ & & 76 & Marco & & $\mathrm{x}$ & 119 & Santana do Cariri & $x$ & $\mathrm{x}$ \\
\hline 30 & Catarina & & $x$ & 77 & Massapê & & $x$ & 120 & São Benedito & $\mathrm{x}$ & \\
\hline 31 & Catunda & & $x$ & 78 & Mauriti & $x$ & $x$ & 121 & São João de Jaguaribe & & $\mathrm{x}$ \\
\hline 32 & Cedro & $\mathrm{x}$ & $\mathrm{x}$ & 79 & Meruoca & & $x$ & 122 & São Luis do Curu & $\mathrm{x}$ & \\
\hline 33 & Choró & & $x$ & 80 & Milagres & $x$ & $x$ & 123 & Senador Pompeu & $x$ & $\mathrm{x}$ \\
\hline 34 & Coreaú & $\mathrm{x}$ & & 81 & Milhã & & $x$ & 124 & Senador Sá & & $\mathrm{x}$ \\
\hline 35 & Crateús & $\mathrm{x}$ & $\mathrm{x}$ & 82 & Miraima & & $x$ & 125 & Sobral & $\mathrm{x}$ & $x$ \\
\hline 36 & Crato & $x$ & $x$ & 83 & Missão Velha & $x$ & $x$ & 126 & Solonópole & $\mathrm{x}$ & $\mathrm{x}$ \\
\hline 37 & Croatá & & $x$ & 84 & Mombaça & $x$ & & 127 & Tabuleiro do Norte & $x$ & $x$ \\
\hline 38 & Dep. Irapuan Pinheiro & & $x$ & 85 & Monsenhor Tabosa & $x$ & $x$ & 128 & Tamboril & $\mathrm{x}$ & $x$ \\
\hline 39 & Ererê & & $x$ & 86 & Morada Nova & $x$ & $\mathrm{x}$ & 129 & Tauá & $x$ & $x$ \\
\hline 40 & Farias Brito & $x$ & $x$ & 87 & Moraújo & & $x$ & 130 & Tejuçuoca & & $x$ \\
\hline 41 & Forquilha & & $x$ & 88 & Morrinhos & & $x$ & 131 & Tianguá & $x$ & $\mathrm{x}$ \\
\hline 42 & Frecheirinha & $x$ & $x$ & 89 & Mucambo & $\mathrm{x}$ & $\mathrm{x}$ & 132 & Tururu & & $x$ \\
\hline 43 & General Sampaio & $\mathrm{x}$ & $\mathrm{x}$ & 90 & Nova Olinda & & $x$ & 133 & Ubajara & $x$ & \\
\hline 44 & Graça & & $\mathrm{x}$ & 91 & Nova Russas & $x$ & $\mathrm{x}$ & 134 & Umirim & & $\mathrm{x}$ \\
\hline 45 & Granja & & $\mathrm{x}$ & 92 & Novo Oriente & $x$ & & 135 & Uruburetama & $x$ & $\mathrm{x}$ \\
\hline $\begin{array}{l}46 \\
47\end{array}$ & $\begin{array}{c}\text { Granjeiro } \\
\text { Groairas }\end{array}$ & & $\underset{x}{x}$ & & & & & $\begin{array}{l}136 \\
137\end{array}$ & $\begin{array}{l}\text { Uruoca } \\
\text { Várzea Grande }\end{array}$ & $x$ & $\begin{array}{l}x \\
x\end{array}$ \\
\hline
\end{tabular}

Figure 2 - Ceará State maps showing the municipalities where National Health Foundation (FUNASA-CE) collected Panstrongylus lutzi. (A) data from 1983, the arrows indicate the municipalities of Sobral and Crateús; (B) data from 2001. 
Table 1 - House units infestation and capture index of Panstrongylus lutzi, in the year 1983 and from 1989 to 2001. (Chagas Disease Control Programme, FUNASA, State of Ceará, Brazil).

\begin{tabular}{lcccccccc}
\hline Year & $\begin{array}{c}\text { Municipalities } \\
\mathrm{n}^{\circ}\end{array}$ & \multicolumn{2}{c}{$\begin{array}{c}\text { Municipalities } \\
\text { with P. lutzi }\end{array}$} & $\begin{array}{c}\text { Houses units } \\
\text { investigated }\end{array}$ & $\begin{array}{c}\text { Infested } \\
\text { houses units }\end{array}$ & $\begin{array}{c}\text { Intradomiciles } \\
\text { infested }\end{array}$ & $\begin{array}{c}\text { P. lutzi capture } \\
\text { index* in }\end{array}$ & $\begin{array}{c}\text { P. lutzi capture } \\
\text { index* in } \\
\text { the house unit }\end{array}$ \\
\cline { 3 - 6 } & & $\mathrm{n}^{0}$ & $\%$ & $\mathrm{n}^{0}$ & $\mathrm{n}^{0}$ & $\mathrm{n}^{0}$ & the intradomicile \\
\hline 1983 & 107 & 84 & 78.5 & 797,910 & 180,358 & 150,658 & 0.4 & 0.5 \\
1989 & 145 & 88 & 60.7 & 639,851 & 68,371 & 32,296 & 0.7 & 1.0 \\
1990 & 151 & 81 & 53.6 & 605,442 & 58,508 & 22,670 & 0.7 & 1.4 \\
1991 & 145 & 84 & 57.9 & 692,052 & 56,279 & 20,506 & 0.8 & 1.5 \\
1992 & 140 & 62 & 44.3 & 661,484 & 51,327 & 18,256 & 0.7 & 1.5 \\
1993 & 162 & 90 & 55.6 & 707,056 & 53,043 & 18,771 & 1.0 & 2.2 \\
1994 & 97 & 50 & 51.5 & 317,234 & 21,502 & 8,027 & 0.9 & 1.9 \\
1995 & 96 & 51 & 53.1 & 425,119 & 25,976 & 8,727 & 0.9 & 1.8 \\
1996 & 96 & 68 & 70.8 & 480,065 & 37,429 & 13,579 & 1.2 & 2.3 \\
1997 & 103 & 58 & 56.3 & 364,904 & 33,934 & 10,142 & 1.2 & 3.4 \\
1998 & 112 & 79 & 70.5 & 410,377 & 39,488 & 16,325 & 1.5 & 3.1 \\
1999 & 99 & 65 & 65.7 & 373,381 & 32,074 & 13,533 & 1.5 & 2.7 \\
2000 & 60 & 27 & 45.0 & 137,334 & 7,466 & 2,716 & 1.9 & 4.5 \\
2001 & 149 & 117 & 78.5 & 589,928 & 52,870 & 16,226 & 1.8 & 4.6 \\
\hline
\end{tabular}

House unit: combination of the house (intradomicile) and the space around the house (peridomicile).

* Capture index = number of triatomine captured : per the number of positive houses unit or positive intradomicile $\mathrm{x} 100$

Table 2 - Presence of Panstrongylus lutzi in domiciliar units in the State of Ceará, Brazil, in the year 1983 and in the period $1989-2001$ (Chagas Disease Control Programme, Fundação Nacional da Saúde, State of Ceará, Brazil).

\begin{tabular}{|c|c|c|c|c|c|c|c|c|c|c|c|c|c|c|c|c|c|c|c|c|}
\hline \multirow[b]{4}{*}{ year } & \multicolumn{16}{|c|}{ Number of triatomines } & & & & \\
\hline & \multicolumn{8}{|c|}{ stage } & \multicolumn{8}{|c|}{ site of capture } & & & & \\
\hline & \multicolumn{4}{|c|}{ adults } & \multicolumn{4}{|c|}{ nymphs } & \multicolumn{4}{|c|}{ intradomicile } & \multicolumn{4}{|c|}{ peridomicile } & \multicolumn{4}{|c|}{ total } \\
\hline & cap & exam & pos & $\%$ & cap & exam & pos & $\%$ & cap & exam & pos & $(\%)$ & cap & exam & pos & $\%$ & cap & exam & pos & $\%$ \\
\hline 1983 & 702 & 84 & 1 & 1.2 & 48 & 10 & 0 & & 689 & 83 & 1 & 1.2 & 61 & 11 & 0 & & 750 & 94 & 1 & 1.1 \\
\hline 1989 & 416 & 104 & 3 & 2.9 & 69 & 38 & 0 & & 338 & 96 & 3 & 3.1 & 147 & 46 & 0 & & 485 & 142 & 3 & 2.1 \\
\hline 1990 & 355 & 77 & 1 & 1.3 & 60 & 32 & 0 & & 319 & 79 & 0 & & 96 & 30 & 1 & 3.3 & 415 & 109 & 1 & 0.9 \\
\hline 1991 & 403 & 119 & 2 & 1.7 & 39 & 30 & 0 & & 301 & 75 & 2 & 2.7 & 141 & 74 & 0 & & 442 & 149 & 2 & 1.3 \\
\hline 1992 & 298 & 91 & 4 & 4.4 & 71 & 36 & 0 & & 268 & 80 & 2 & 2.5 & 101 & 47 & 24.3 & & 369 & 127 & 4 & 3.1 \\
\hline 1993 & 480 & 99 & 2 & 2.0 & 48 & 19 & 1 & 5.3 & 421 & 78 & 2 & 2.6 & 107 & 40 & 12.5 & & 528 & 118 & 3 & 2.5 \\
\hline 1994 & 163 & 39 & 1 & 2.6 & 24 & 8 & 0 & & 156 & 35 & 1 & 2.9 & 31 & 12 & 0 & & 187 & 47 & 1 & 2.1 \\
\hline 1995 & 180 & 41 & 1 & 2.4 & 50 & 31 & 0 & & 157 & 37 & 1 & 2.7 & 73 & 35 & 0 & & 230 & 72 & 1 & 1.4 \\
\hline 1996 & 386 & 97 & 1 & 1.0 & 58 & 38 & 0 & & 306 & 64 & 1 & 1.6 & 138 & 71 & 0 & & 444 & 135 & 1 & 0.7 \\
\hline 1997 & 373 & 136 & 4 & 2.9 & 43 & 16 & 0 & & 344 & 123 & 3 & 2.4 & 72 & 29 & 13.4 & & 416 & 152 & 4 & 2.6 \\
\hline 1998 & 543 & 254 & 9 & 3.5 & 67 & 37 & 0 & & 500 & 224 & 5 & 2.2 & 110 & 67 & 4 & 6.0 & 610 & 291 & 9 & 3.1 \\
\hline 1999 & 431 & 141 & 7 & 5.0 & 56 & 32 & 1 & 3.1 & 371 & 118 & 6 & 5.1 & 116 & 55 & 23.6 & & 487 & 173 & 8 & 4.6 \\
\hline 2000 & 127 & 67 & 1 & 1.5 & 14 & 6 & 0 & & 122 & 64 & 0 & 19 & 9 & 1 & 11.1 & & 141 & 73 & 1 & 1.4 \\
\hline 2001 & 878 & 303 & 6 & 2.0 & 70 & 56 & 1 & 1.8 & 747 & 245 & 4 & 1.6 & 201 & 114 & 3 & 2.6 & 948 & 359 & 7 & 1.9 \\
\hline
\end{tabular}

Cap $=$ captured. Exam $=$ examined. Pos $=$ positive for Trypanosoma cruz $i$ infection

$\left(\mathrm{F}^{2}, \mathrm{p}=0.9\right)$ but the average numbers of bugs captured did show some increase over this period. For 1983, the average number of bugs encountered was 0.4 per domestic unit examined, rising to 1.8 in 2001 ( $\mathrm{p}<0.05)$. This increase was most marked in intradomestic captures, which rose from averages of 0.5 to 4.6 $(\mathrm{p}<0.05)$ over this period (Table 1). Rates of infection of the adult bugs with $T$. cruzi varied between 1 to $5 \%$ over the period considered, with only 3 nymphs found to be infected (Table 2).

Our searches for silvatic bugs revealed two adult females P. lutzi in hollow trunks of pau branco (Auxemma oncocalyx), a tree of the Borraginaceae family, near the town of Sobral (Figure $4 \mathrm{~A}$ and $4 \mathrm{~B})$. In Crateús, no bugs were found by microhabitat examination, but two males were taken at the light trap.
From the bugs collected in domestic and peridomestic habitats of Crateús and Sobral, a clear distinction was observed in terms of color pattern. Those from Crateús were invariably paler in color, while the majority of those from Sobral (74\% of 50 examined) were a much darker brown (Figure 5). Amongst these bugs, common principal component analysis indicated that the Sobral insects tended to be larger (both for males and females) with a marked differentiation between the two populations (Figure 6A). Likewise, discriminant analysis of shape components demonstrated separation between the two populations (Figure 6B). 


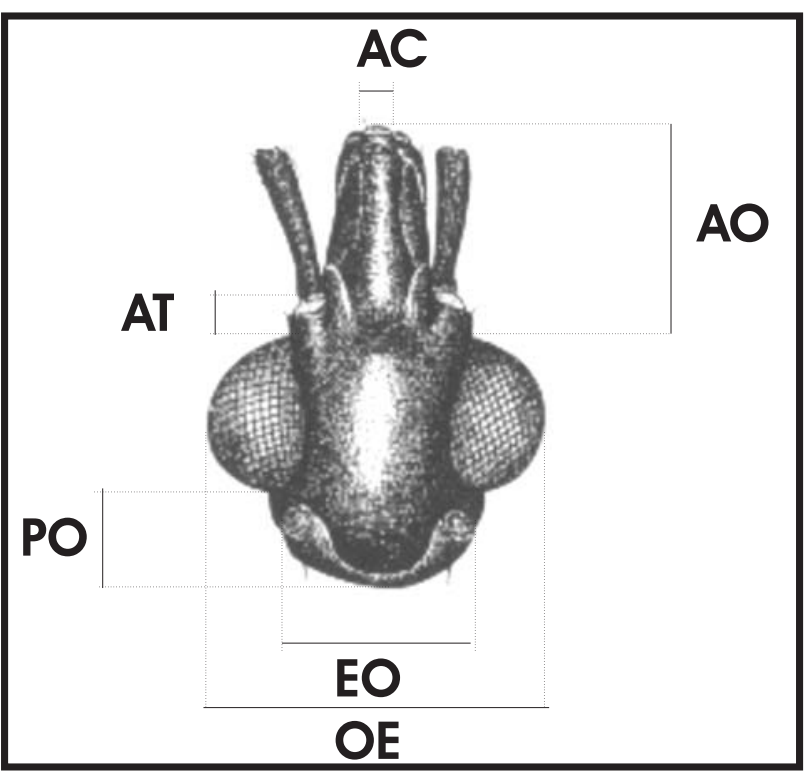

Figure 3 - Dorsal aspects of an adult Panstrongylus lutzi head, showing the morphometric measurements taken. AC, width of anteclypeus; AT, length of antenniferous tubercle; AO, anteocular distance; EO, external distance between occelli; OE, external distance between eyes and; PO, postocular distance excluding neck.
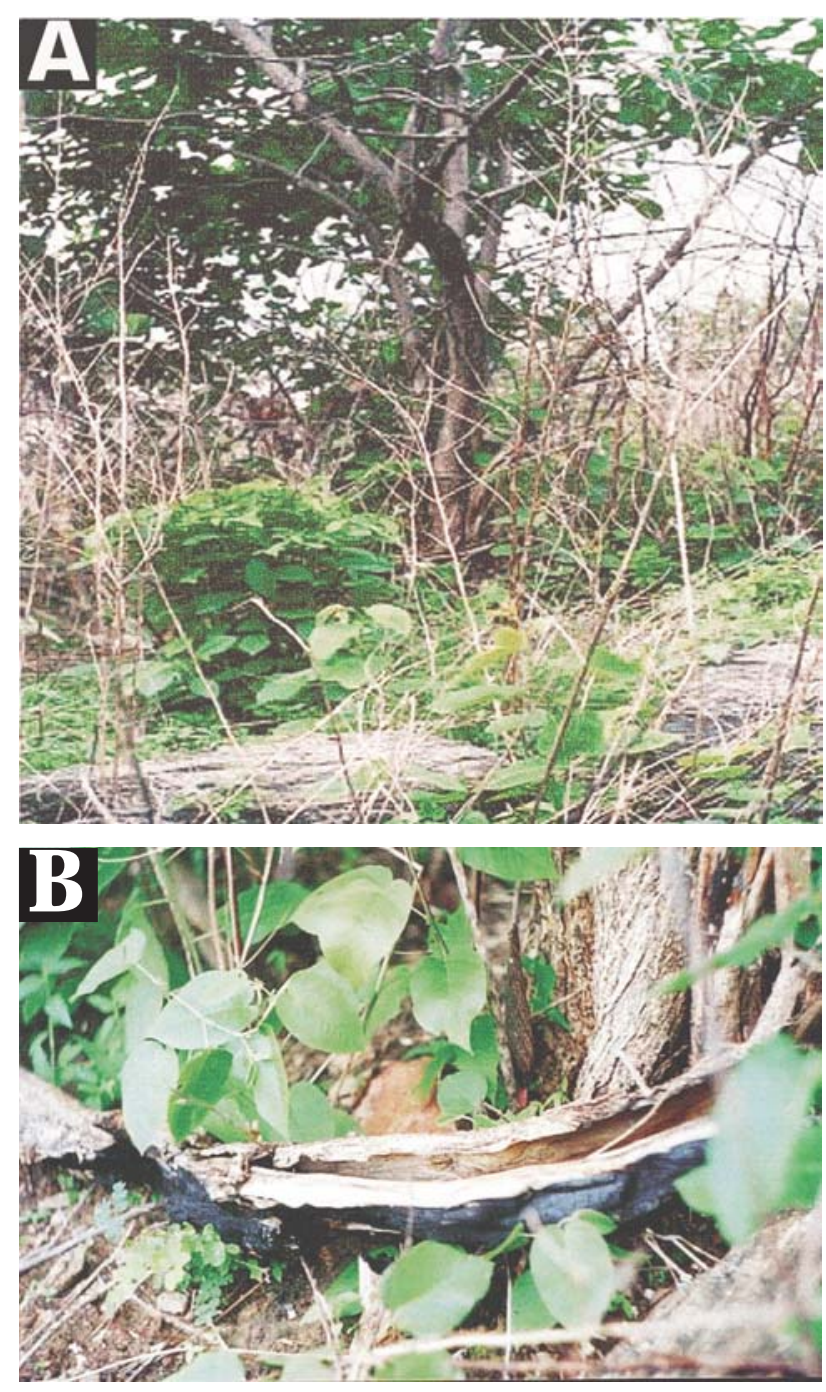

Figure 4 - Natural ecotopes of Panstrongylus lutzi in the State of Ceará, Brazil. (A) "Caatinga" view; (B) Detail of a bollow trunks of "pau branco" (Auxemma oncocalyx), where the triatomines were captured.
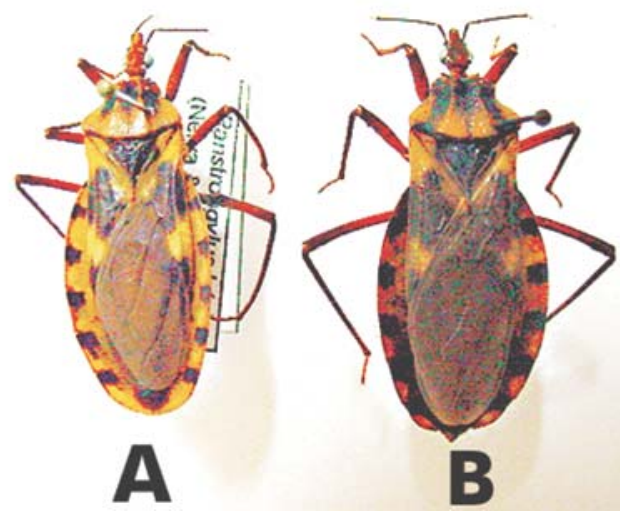

Figure 5 - Male and female of Panstrongylus lutzi collected in the municipalities of Crateús (A) and Sobral (B), Ceará State, Brazil and maintained in the entomological collection.

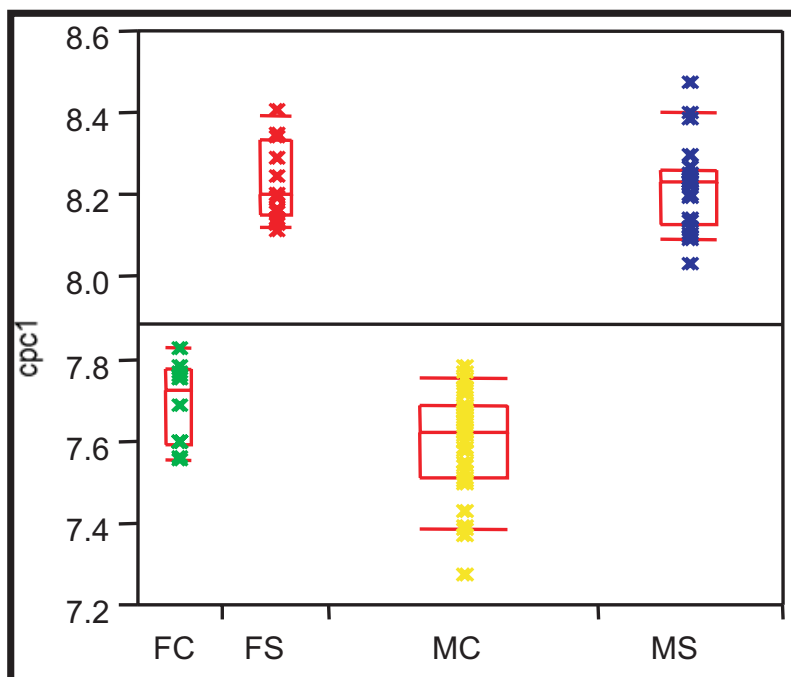

(A) First Common Principal Component - Size

FC: female Crateús. FS: male Sobral MC: male Crateús. MS: male Sobral

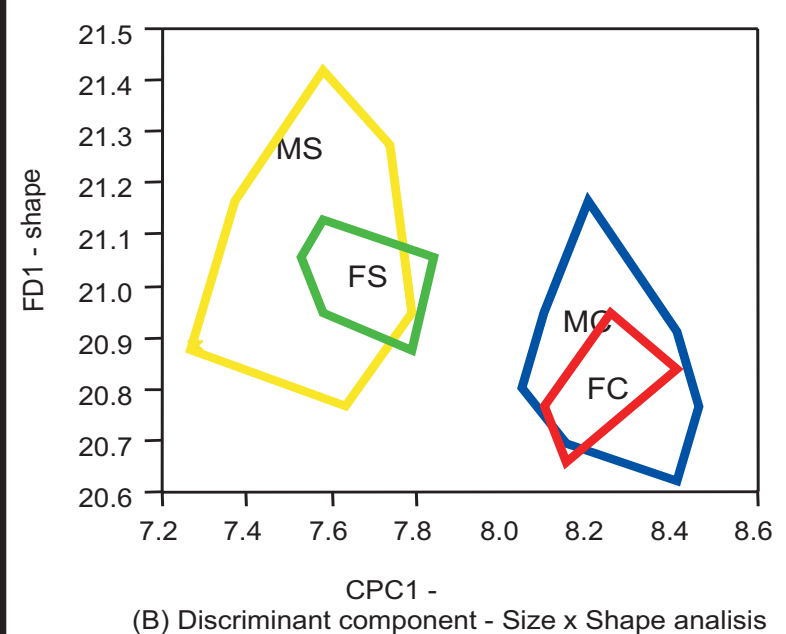

FC: female Crateús. FS: male Sobral MC: male Crateús. MS: male Sobral

Figure 6 - Multivariate analysis showing the distribution of males and females Panstrongylus lutzi from two different populations. (A) Common principal component analyses, that shows the global size of the insects. (B) Discriminant analysis showing both size and shape relationships. 
Comparison of male genitalia showed vesical forms amongst bugs from Crateús that were consistent with those described for both $P$. lutzi and P. sherlocki, whereas bugs from Sobral all showed vesical forms compatible with $P$. sherlocki. The endosomal process was similar in all bugs examined, generally displaying numerous apical spines (Table 3).

Table 3 - Comparison of phallic structures of Panstrongylus lutzi collected in Crateús and Sobral, Ceará, Brazil.

\begin{tabular}{lcccc}
\hline & \multicolumn{2}{c}{ Pattern of the vesica } & & Apical process of endosoma \\
\cline { 2 - 3 } $\begin{array}{l}\text { number of insects } \\
\text { compatible } \\
\text { with } \text { P. lutzi }\end{array}$ & $\begin{array}{c}\text { number of insects } \\
\text { compatible }\end{array}$ & & with P. sherlocki \\
Origin & 5 & 5 & Many spines \\
\hline Crateús $(\mathrm{n}=10)$ & 0 & 9 & Many spines \\
Sobral $(\mathrm{n}=9)$ & 0 & &
\end{tabular}

\section{DISCUSSION}

The main domestic vector of Chagas disease in the State of Ceara is Triatoma brasiliensis, and in our baseline year of 1983, the Chagas disease Programme of Ceará (PCDCh) captured a total of 210,439 specimens of this species ${ }^{12}$. By 2001 however, with a broadly similar capture effort, the total number of T. brasiliensis collected had declined to 55,280 specimens ${ }^{13}$. During the same period, a total of 750 specimens of $P$. lutz $i$ was captured in 1983 , compared to 948 specimens in 2001 - of which $93 \%$ were adults (Table 2). In other words, although the vector control interventions appear to have markedly reduced the capture rate of $T$. brasiliensis, they appear to have had little effect on the frequency of house invasion by $P$. lutzi. Moreover, the capture index for $P$. lutzi (number of bugs captured/ number of houses infested $x$ 100) shows a steady increase over this period (Table 1), with greater frequency of house invasion. This is also paralleled by increasing reports of nymphs recorded in peridomestic habitats in $21.4 \%$ of the municipalities examined in 2001 , and in intradomestic habitats in $12 \%$ of these municipalities.

The available data suggest that $P$. lutzi is increasingly likely to invade peridomestic and domestic habitats, and also increasingly likely to form peridomestic and domestic colonies. Discussion with householders in Sobral and Crateús revealed that adult $P$. lutzi are often seen flying into the houses - presumably attracted by light as indicated by our captures at light traps. Moreover, although infection rates with T. cruzi were relatively low (Table 2) invasion of houses by silvatic $P$. lutz $i$ would appear to represent an additional mechanism to introduce silvatic strains of $T$. cruz $i$ into the domestic transmission cycles.

Comparing the distributional maps for 1983 and 2001 (Figure 3), it appears that domestic colonies of $P$. lutzi were concentrated along the central and western regions of the state of Ceará, towards the neighboring state of Piauí - without any apparent association with the reported distribution of other species of Triatominae, nor with obvious geographic or anthropic factors. It is possible that the frequency of domestic invasion reflects the frequency of its occurrence in silvatic habitats ${ }^{515}$, which in turn may reflect the density of silvatic hosts such as armadillos ${ }^{10}$. Our finding of adult $P$. lutzi in hollow trees could indicate an alternative silvatic habitat, although given the widespread association of species of Panstrongylus with armadillo burrows ${ }^{8}$ this finding could equally be due to adventitious flying adult bugs.

The P. lutzi populations studied here showed marked variability in morphology, shown by colour and metric characteristics of the head capsule. In particular, comparison of anteocular and postocular distances, and length of antenniferous tubercle (Figure 5), allowed clear distinction between populations from Sobral and Crateús. Those of Sobral were invariably larger than those from Crateús, which may indicate a west-east axis of differentiation, since other studies have indicated that derivative populations are generally of smaller average size than their putative original forms?

\section{REFERENCES}

1. Ab'Saber NA. Participação das superfícies aplainadas nas paisagens do Nordeste Brasileiro. Geomorfologia, São Paulo 19: 1-138, 1969.

2. Alencar JE. História Natural da Doença de Chagas no Estado do Ceará. Imprensa Universitária da UFC, Fortaleza, 1987.

3. Alencar JE, Santos AR, Bezerra OF, Saraiva TM. Distribuição geográfica dos principais vetores de endemias no Estado do Ceará. - I - Triatomíneos. Revista da Sociedade Brasileira de Medicina Tropical 10: 261-284, 1976.

4. Barbosa SE, Dujardin JP, Soares RPP, Pires HHR, Margonari C, Romanha AJ, Panzera F, Linardi PM, Duque-De-Melo M, Pimenta PFP, Pereira MH, Diotaiuti L. Interpopulation variability among Panstrongylus megistus (Hemíptera: Reduviidae) from Brazil. Journal of Medical Entomology 40: 411-420, 2003.

5. Barretto MP. Epidemiologia. In: Brener Z, Andrade Z. Trypanosoma cruzi e Doença de Chagas. Guanabara Koogan, Rio de Janeiro, 1979

6. Borges EC, Dujardin JP, Schofield CJ, Romanha AJ, Diotaiuti L. Genetic variability of Triatoma brasiliensis Neiva, 1911 (Hemiptera: Reduviidae: Triatominae) populations. Journal of Medical Entomology 37: 872-877, 2000.

7. Carcavallo RU, Rodrigués MEF, Salvatella R, Casas SIC, Sherlock IS, Galvão C, Rocha DS, Girón IG, Arocha MAO, Martinez A, Rosa JA, Canale DM, Farr TH, Barata JM. Habitats and related fauna. In: Carcavallo RU, Girón IG, Jurberg J, Lent H. Atlas dos Vetores da Doença de Chagas nas Américas, Editora Fundação Oswaldo Cruz, Rio de Janeiro, Vol. II, p.561-600, 1997.

8. Dias-Lima AG, Menezes D, Sherlock I, Noireau F. Wild habitat and fauna of Panstrongylus lutzi (Reduviidae: Triatominae). Journal of Medical Entomology 40: 989-990, 2003

9. Dujardin JP. Introducción a la morfometria con énfasis en Triatominae y Phlebotominae. European Community and Latin American Network for Research on the Biology and Control of Triatominae/ECLAT website: http:/ /eclat.fcien.edu.uy, 2001

10. Dujardin JP, Forgues G, Torrez M, Martinez E, Cordoba C, Gianella A. Morphometrics of domestic Panstrongylus rufotuberculatus in Bolivia. Annals of Tropical Medicine and Parasitology 9:219-228, 1998.

11. Fundação Nacional da Saúde. Coordenação do Estado do Ceará. Arquivos estatísticos, Divisão de Epidemiologia, Ministério da Saúde, 1983.

12. Fundação Nacional da Saúde. Coordenação do Estado do Ceará. Arquivos estatísticos, Divisão de Epidemiologia, Ministério da Saúde, 2001.

13. Jurberg J, Carcavallo RU, Lent H. Panstrongylus sherlocki sp.n do Estado da Bahia, Brasil (Hemiptera, Reduviidade, Triatominae). Entomologia y Vectores 8: 261-274, 2001.

14. Lent H, Jurberg J. 0 gênero Panstrongylus Berg, 1879, com um estudo sobre a genitália externa das espécies (Hemiptera, Reduviidae, Triatominae). Revista Brasileira de Biologia 35: 379-438, 1975.

15. Ministério das Minas e Energia. Projeto RADAMBRASIL. Folhas SB. 24/25 Jaguaribe/Natal; geologia, geomorfologia, pedologia, vegetação e uso potencial da terra. Rio de Janeiro, 1981.

16. Rohlf FJ. NTSYS-pc: numerical taxonomy and multivariate analysis system, version 2.0, user guide. Exeter Software, New York, 1998.

17. Statistical Analysis Software Institute. JMP Statistics and Graphics Guide, version 3:1. Cary, NC, 1995. 